\title{
ROMANI LANGUAGE DEVELOPMENT OF PRESCHOOL ROMA CHILDREN
}

\author{
Hristo Kyuchukov \\ Magdeburg-Stendal University of Applied Sciences \\ 2 Breitscheid straße, Magdeburg, 39114, Germany \\ Milan Samko \\ Constantine the Philosopher University \\ 1 Trieda Andreja Hlinku, Nitra-Chrenová, 949 74, Slovak Republic
}

The paper aims to present the acquisition of some grammatical categories in Romani language by children aged 3 and 6 years old. Roma children from Bulgaria and from Slovakia were tested with a test in Romani language. Categories such as wh-questions, wh complements, passive verbs and possessiveness are measured with newly developed test.

The knowledge of the children is connected with the theory of García Coll and her collaborators (1996), who present the home environment and the SES of the families as an important predictor for language development.

Key words: Roma children, Romani, language development

\section{INTRODUCTION}

The researches with children show that all normally developing children follow the same "pats" in their language evolution. First the sound system, then the vocabulary, the syntax and later the ability to narrate are developed (Tomasello, 2003 [1]; Roskos and Neuman, 2005 [2]; Neuman and Marulis, 2010 [3]). The Roma children are not exception in this process of language development. The only difference is the use of different strategies and approaches for language development used by Roma parents, which are part from the Roma culture (fairytales, folksongs, teasing, and language games). In Roma communities everyone is free to communicate and play with children. In extended families children are exposed to different registers speaking with parents, adults and siblings (Kyuchukov, 2014 [4]; Kyuchukov, Kaleja \& Samko, 2016 [5]).

In this article, we adapt the model for the study of child development of Garcia Coll et al. (1996) in the U.S. and which addresses the children of color. The authors present an integrative model of child development, drawing on Parsons' (1940) social stratification theory emphasizing the influence of racism, prejudice, discrimination, oppression, and segregation on the development of minority families and children (Garcia Coll et al., $1996[6])$.

According to Bronfenbrenner $(1979,1986$ [7; 8]), the family's interaction with other groups and institutions affects the way of children's adaptation to non-familial environments 
(e.g. school). Influential factors of these children's social and communicative success at school are: parents' level of education, employment, the parent-child relationship, home environment, and resources available inside and outside of home. Ogbu (1978, 1981, 1988) [based on Han, 2006 [9]] adapted Bronfenbrenner's theory, applying it to emigrant children's families, with an emphasis on the importance of the culture. García Coll et al. [6] stress the importance of the surrounding environment on behavioral, emotional, and cognitive development of the children. The neighborhood and school environment either promote or inhibit minority children's development [9]. According to Han the social position of a group of people, the racism and segregation directed against them, are considered to be important factors in the educational process. García Coll et al. [6] do not underestimate the role of the culture in the learning process of minority children. The extended families, the community and friends help them to learn new things in everyday life. Han [9] stresses:

Additionally, child/parent/family characteristics, home environment and parental educational practices (e.g., learning activities at home, participation in extracurricular activities and school events), and school (e.g., student composition and average academic performance, parental involvement, school safety) and neighborhood (e.g., residential neighborhood quality) environments are considered possible mediating factors for any such associations [9. P. 288].

Forget-Dubois et al. [10] argue that the features of home environment are significantly predictive on later language skills. The SES and maternal speech are very important for vocabulary development. Language skills and school readiness are also correlated. The children with low SES but with higher language competence evince a good level of school readiness. The relation between language development and school readiness is not only a predictor of school achievement but is also itself a school readiness measure.

Rydland [11], doing research among bilingual Turkish children from Norway, investigated their pretended play. Through pretended play the children develop complex language skills and basic narrativity. The highly developed oral skills show pragmatic language competence in the mother tongue of the children, which is important for second language acquisition.

The aim of the article is to present results from an international research showing the level of knowledge of Romani as a mother tongue among Roma children in Bulgaria and Slovakia. The research question we've tried to answer with this study is:

Which grammatical categories the normally developing Roma children know in their mother tongue at the age of 3-6 years old?

\section{Methodology}

The research included 60 Roma children between 3-6 years old: 30 children from Bulgaria and 30 children form Slovakia. All the children were selected randomly. They were grouped in three age groups:

-1 gr. 10 children between $3 ; 0-3 ; 11$ years old

-2 gr. 10 children between $4 ; 0-4 ; 11$ years old

-3 gr. 10 children between $5 ; 0-6 ; 0$ years old

The children were tested in their mother tongue - varieties of Romani language. Roma in Slovakia and Roma in Bulgaria speak different dialects, but still the language is 
the same. The children were tested in community centers by speakers of the two particular dialects. They do not attend kindergarten and most of the knowledge they acquire about the world is obtained through communication with the family members.

Three picture tests were used for testing the language knowledge of Roma children in their mother tongue:

Test 1: Wh- questions (Who eats what?) -8 items - production test. The children were showing 8 pictures with different actions done by the protagonists and the children were asked questions regarding the actions. In some languages when there are two $w h$ words at the beginning of the sentence the first $w h$ word is answered and in some other languages - the second $w h$ word. The expectation form the children is that they will answer the both $w h$ words in the sentence.

Test 2: Passive verbs (The dog was kicked by the horse) - 16 items - comprehension test with multiple choice. The test measures the knowledge of the children of passive tests. The children usually understand sentences such as: The dog kicks the horse. But it is more difficult to understand sentences such as: The dog was kicked by the horse.

Test 3: Possessiveness (The horse has a balloon. This is not your balloon. This is the...) 26 items - production test. The test is based on Berko's Wug test (1958) [12], where the children have to fill in orally the missing word, in this case the possessive endings in Romani for masculine and feminine and for singular and plural with known objects as well as with novel ones.

The tests were adapted to the local dialects spoken by Roma from the two communities in Bulgaria and in Slovakia.

Our hypothesis is:

The SES of the families influence the language development of their children.

\section{RESULTS}

The findings from the first test, $\mathrm{Wh}$ - questions, shows that between the age groups there are statistically significant differences. The first age group from both countries (3-4 years old) showed lower results in comparison to the third age group (5-6 years old). Figure 1 shows the total score of the first test as a function of age group.

The impact of the factor Age group on the Total scores of Wh-questions test as a dependent variable is statistically significant $(F=12,94 ; p<0,0001)$. Size effect is large $\left(\eta^{2}=0,34\right)$. The Post Hoc Tests show that between all the groups, there are statistically significant differences. Comparing the results of the children between the two countries, one can see that the Roma children from Bulgaria have higher results than the Roma children from Slovakia.

The impact of the factor country on the Total scores of Wh-questions test as a dependent variable is statistically significant $(F=20,28 ; p<0,0001)$. Size effect is medium $\left(\eta^{2}=0,28\right)$. The Roma children from Bulgaria perform this test much better than the Slovak Roma children.

In the performance of the second test on passive verbs, the age groups again show statistical differences. Figure 2 indicates that older children from both countries understand and complete the tasks much better than the younger children. The results are plotted in Figure 2. 
Кючуков Х., Самко М. Вестник РУДН. Серия: Вопросы образования: языки и специальность. 2017. T. 14. № 4. C. 595-603

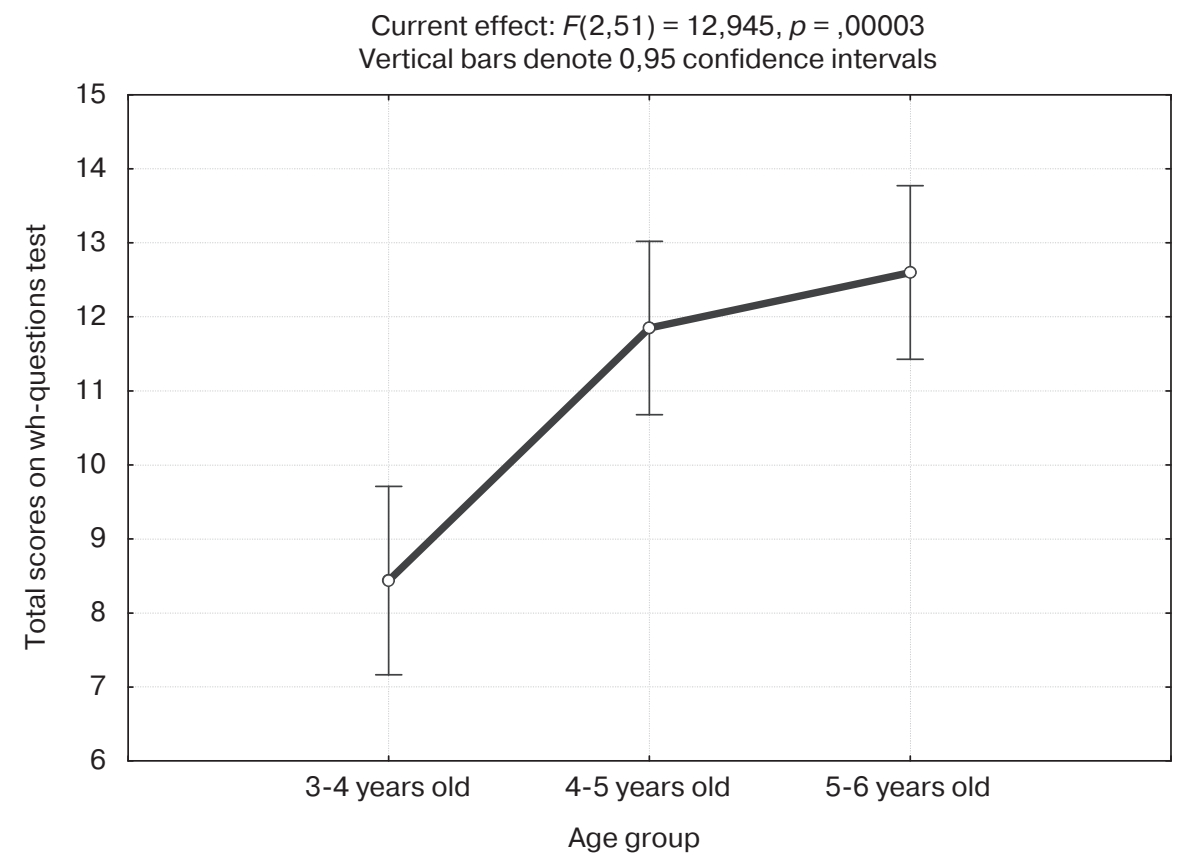

Figure 1. Total Scores on Wh-questions Test as a Function of Age Group

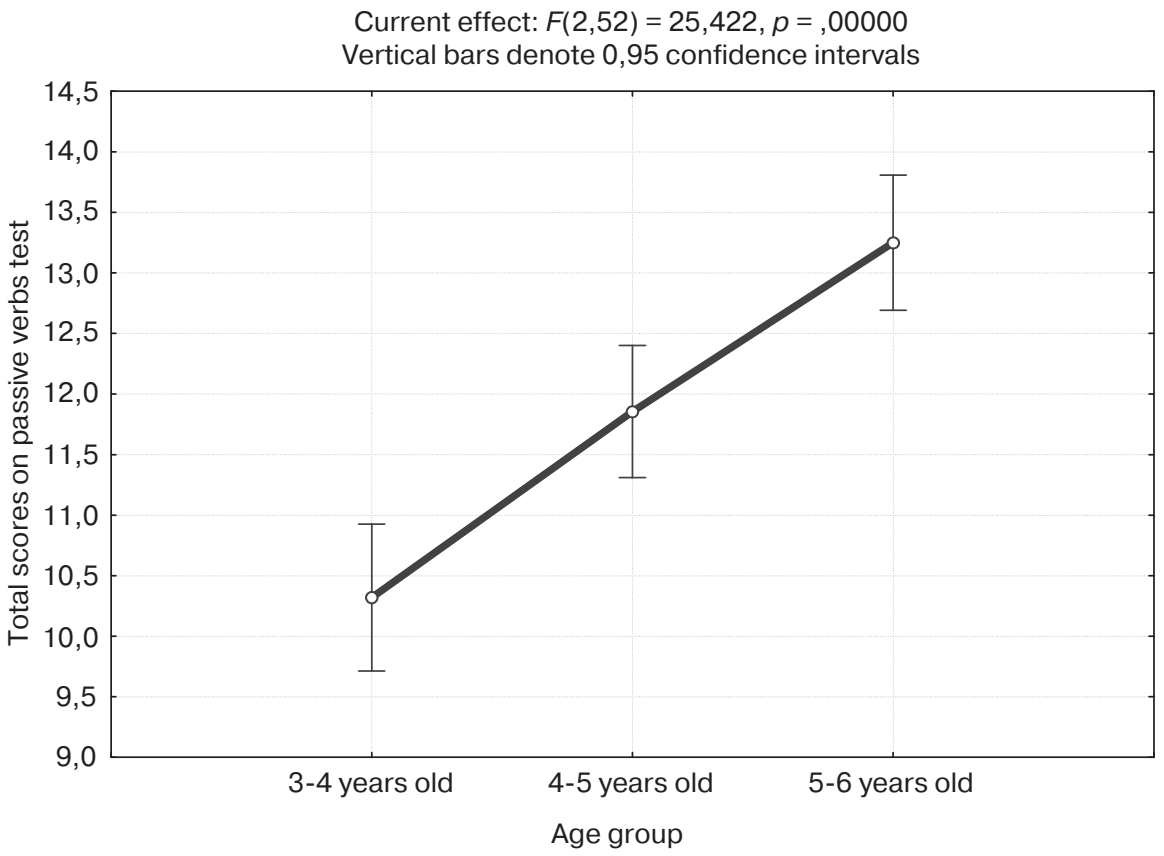

Figure 2. Total Scores on Passive Verbs Test as a Function of Age Group

The impact of the factor Age group on the total scores on the passive verbs test as a dependent variable is statistically significant $(F=25,42 ; p<0,0000)$. Size effect is large $\left(\eta^{2}=0,49\right)$. The Post Hoc Analyses show that the differences between all three groups are statistically significant. Comparing the children from the two countries, one can see 
that again the Bulgarian Roma children perform this test much better. The impact of the factor country on the total scores on passive verbs test as a dependent variable is statistically significant $(F=35,45 ; p<0,0000)$. The size effect is large $\left(\eta^{2}=0,41\right)$. Again the Bulgarian children are much better than the Slovak children.

How did the children perform in the third test, relating to the possessive? The results are given in Figure 3.

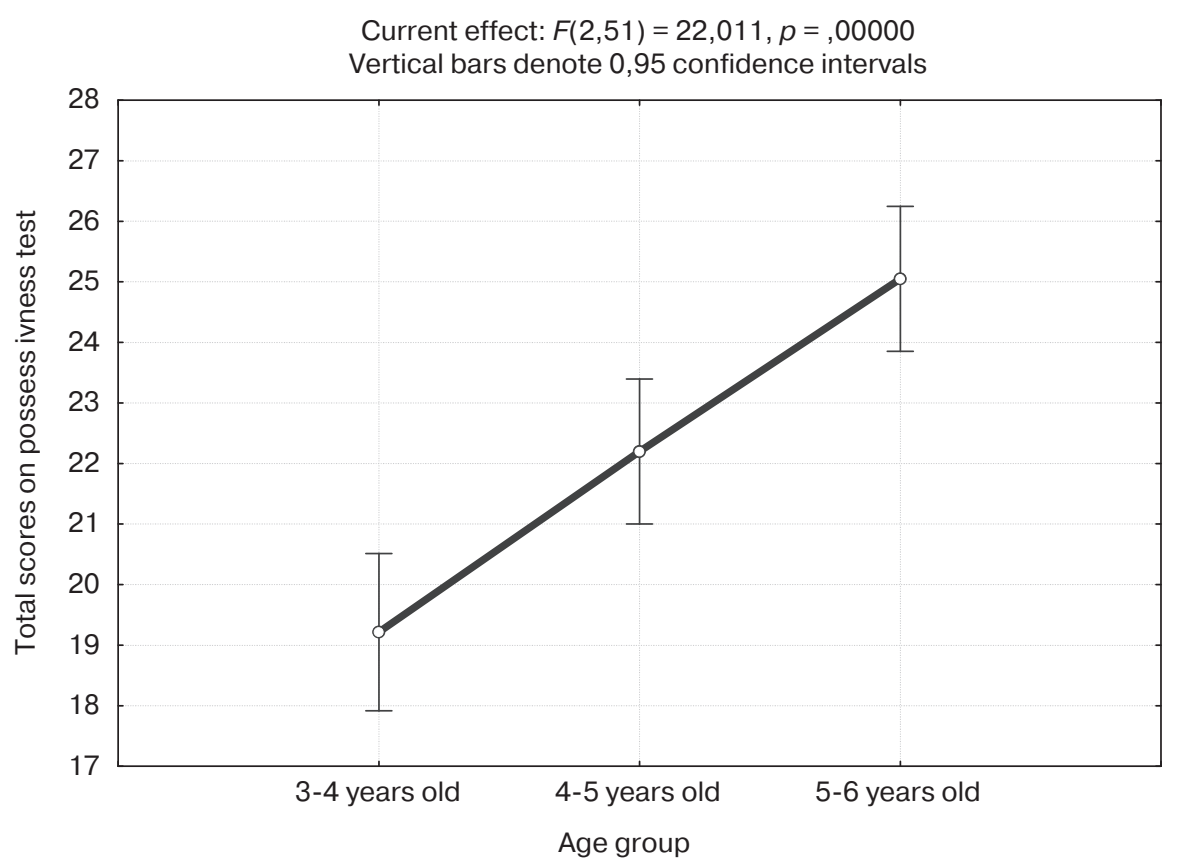

Figure 3. Total Scores on Possessiveness Test as a Function of Age group

The impact of the factor Age group on the total scores on the Possessiveness test as a dependent variable is statistically significant $(F=22,01 ; p<0,0000)$. Size effect is large $\left(\eta^{2}=0,46\right)$. Again the older children from both countries are much better than the younger children. The Post Hoc analyses show that the differences between the three groups are statistically significant. How did the children perform this test by country? The impact of the factor country on the Total scores on the Possessiveness test as a dependent variable is statistically significant $(F=39,86 ; p<0,0000)$. The size effect is large $\left(\eta^{2}=0,44\right)$. Again the Bulgarian Roma children are much better than the Slovak Roma children.

Figure 4 shows the total scores on the Possessiveness test as a function of interaction between factors age group and country.

Figure 4 clearly shows that all age groups form Bulgaria perform in the Possessiveness test much better than the Roma children from Slovakia. The impact of the interaction between factors Age group and Country on the total scores on the possessiveness test as a dependent variable is statistically significant $(F=6,46 ; p<0,01)$. The size effect is medium $\left(\eta^{2}=0,20\right)$. The Post Hoc analyzes show the differences between groups by country and one can see that between the first and second groups from both countries, the differences are statistically significant, but between the third age groups there are no statistically significant differences. 


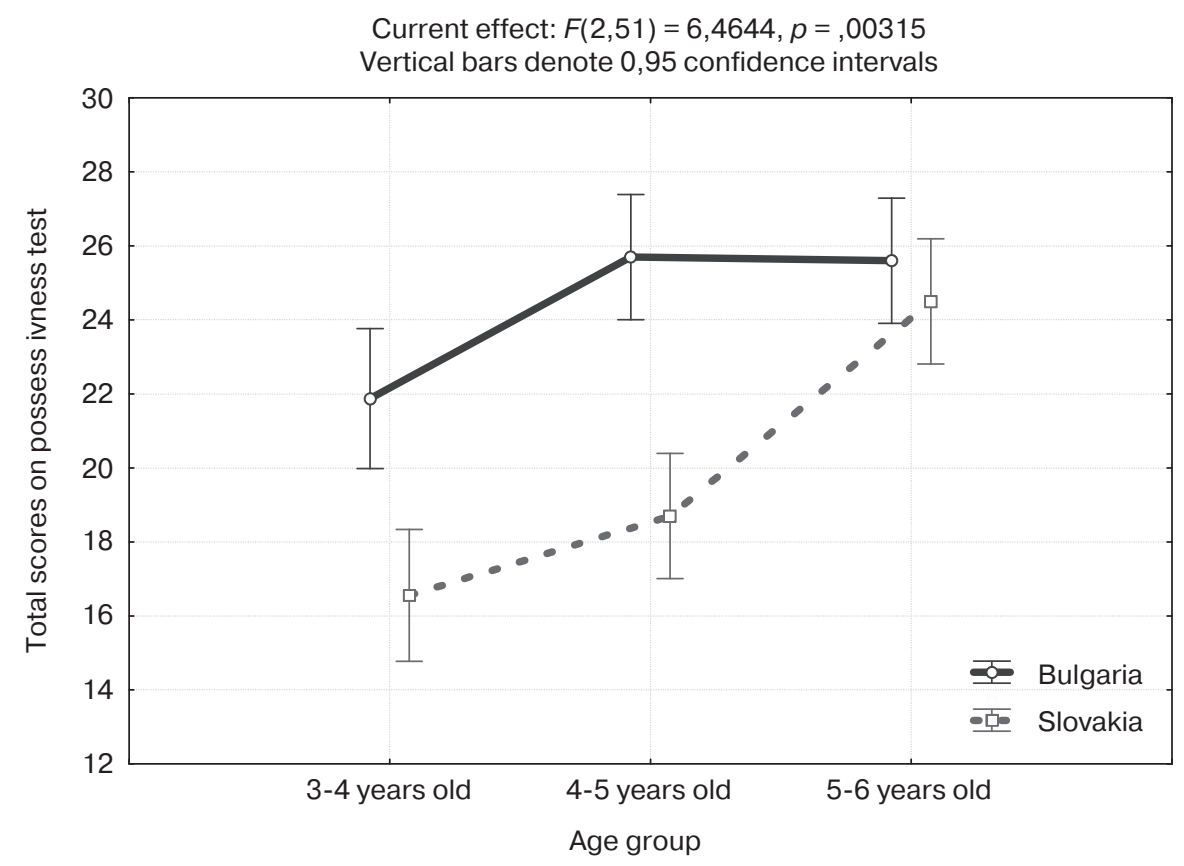

Figure 4. Total scores on Possessiveness Test as a Function of interaction between factors Age group and Country

\section{DISCUSSION AND CONCLUSIONS}

Coming back to the hypotheses of the study, it seems that our hypothesis is confirmed. We see that the SES of the families influence the language development of the children as it is stated by García Coll et al. [6]. The Roma children from Bulgaria, although they live in a ghetto-like settlement, have much better conditions in comparison with the Roma children from Slovakia. It seems that the Slovak Roma children grow up in highly deprived conditions (in some of cases very close to the conditions prevailing in some African countries) and lack access to toys, books, TV, internet and other facilities. Growing up stigmatized as Roma with all the negative stereotypes and prejudices in the society against Roma confirms the theory of García Coll and her collaborators that all the negative phenomena and attitudes in the societies towards minority groups (such as racism and discrimination) influence the development of the families and their children. In this case, the Roma children do not have the necessary knowledge in their mother tongue, because the isolation and segregation in which they live and grow up do not give them a natural possibility to become socialized in the society as is the normal case with children from the majority population. However, the newest study by Hryniewicz and Dewaele (2017) [13] with Slovak Roma children in UK, shows that in a new situation and in a new country the children attend public schools, and get socialized, preserving their language and identity, because the attitudes towards them is not so negative as it is in Slovakia.

Opposite to the Slovak Roma children, the Bulgarian children, although living in a ghetto-like settlement, have much better conditions and more contacts with the majority society, because the settlement is not so far from the town. Moreover, most of the children here have much better conditions at home. The Protestant church also plays an important 
role in their life. Organized religious cultural activities such as summer schools, Sunday schools, excursions, bring together Roma and non-Roma and helps the children from early ages to have a different behavior and to get different types of socialization. So there are an ensemble of factors influencing the life of the Bulgarian Roma children in a positive way.

Romani language, being mainly an oral language, is learned by the children from oral communication and the rich folkloristic culture such as songs, fairy tales, teasing, jokes and other genres of folklore. It seems that the complex language development of Roma children cannot be reached until the age of 5-6 years old. Even when they do not attend kindergarten and do not have good conditions at home, between the ages of 5 to 6 they learn the most complex grammatical structures, as shown by the test for possessiveness. The children 5-6 years old from Bulgaria and Slovakia reach the same level of complex grammatical knowledge, performing the possessiveness test and this can be taken as an indicator for school readiness. All the research findings with Roma children are contrary to the claims of Bakalar (2004) [14] and Cvorovic (2014) [15], [16] that the problem of the integration of Roma children is the knowledge of the Romani as a mother tongue.

(C) Kyuchukov H., Samko M., 2017

\section{REFERENCES}

1. Tomasello, M. Constructing a language: A usage-based theory of language acquisition. Cambridge, MA: Harvard University Press, 2003.

2. Roskos, K., \& Neuman, S. The state of pre-kindergartens standard. Early Childhood Research Quarterly, 20, 125-145. 2005.

3. Neuman, S., \& Marulis, L.M. The Effects of Vocabulary Intervention on Young Children's Word Learning: A Meta-Analysis. Review of Educational Research, 2010. 80 (3), 300-335.

4. Kyuchukov, H. Acquisition of Romani in a Bilingual Context. Psychology of Language and Communication, 2014. 18 (3), 211-225.

5. Kyuchukov, H., Kaleja, M. \& Samko, M. Roma parents as educators of their children. Intecultural education. 2016. 26 (5), 444-448.

6. García Coll, C., Lamberty, G., Jenkins, R., McAdoo, H.P., Crnic, K., Wasik, B.H. and García, H.V. An Integrative Model for the Study of Developmental Competencies in Minority Children. Child Development. 1996. 67 (5), 1891-1914.

7. Bronfenbrenner U. The ecology of human development: Experiments by nature and design. Cambridge, MA: Harvard University Press, 1979.

8. Bronfenbrenner U. Ecology of the family as a context for human development: Research perspectives. Developmental Psychology, 1986. 22, 723-742.

9. Han W.-J. Academic Achievements of Children in Immigrant Families. Educational Research and Review. 2006. 1 (8), 286-318.

10. Forget-Dubois N., Lemelin, J.-P., Perusse, D., Tremblay, R.E. \& Boivin, M. Early Child Language Mediates the Relation Between Home Environment and School Readiness. Child Development, 2009. 80 (3), 736-749.

11. Rydland V. "Whow-when I was going to pretend drinking it tasted coke for real!" Second-language learners' out-of-frame talk in peer pretend play: A developmental study from preschool to first grade. European Journal of Developmental Psychology, 2009. 6, (2), 190-222.

12. Berko, J. The child's learning of English morphology.1958. Word, 14, 150-177.

13. Hryniewicz, L. \& Dewaele, J.-M. Exploring the intercultural identity of Slovak-Roma schoolchildren in the UK. Russian Journal of Linguistics, 2017. 21 (2), 282-304. 
14. Bakalar, P. The IQ of Gypsies in Central Europe. The Mankind Quarterly, XLIV, (3\&4), 2004. 291-300.

15. Cvorovic, J. The Roma: A Balkan Underclass. Ulster: Ulster Institute for Social Research. 2014.

16. Parsons, Talcott. An Analytical Approach to the Theory of Social Stratification. American Journal of Sociology. 45 (6), 841-862.

\title{
Article history:
}

Received: 19.06 .2017

Accepted: 21.08.2017

Moderator: U.M. Bakhtikireeva

\section{Conflict of interests: none}

\section{For citation:}

Kyuchukov H., Samko M. (2017). Romani Language Development of Preschool Roma Children. RUDN Journal of Language Education and Translingual Practices, 14 (4), 595-603. DOI 10.22363/2312-8011-2017-14-4-595-603

\section{Bio Note:}

Kyuchukov Hristo is a Doctor of Pedagogical Sciences, Professor of Magdeburg-Stendhal University of Applied Sciences, Magdeburg, Germany. E-mail: hkyuchukov@gmail.com

Samko Milan is a Doctor in Philosophy (PhD), Associate Professor of the Institute of Romani Studies of the University of Constantine the Philosopher, Nitra, Slovakia. E-mail: msamko@ukf.sk

\section{РАЗВИТИЕ РУМЫНСКОГО ЯЗЫКА У ДЕТЕЙ-ДОШКОЛЬНИКОВ}

\author{
Христо Кючуков \\ Магдебург-Стендальский университет прикладных наук \\ Германия, 39114, Магдебург, Брайтчайд штрассе, 2

\section{Милан Самко} \\ Университет им. Константина Философа \\ Словакия, 949 74, Нитра, Триеда Андрея Глинку, 1
}

Рассматривается проблема формирования у детей-румын в возрасте $3-6$ лет некоторых грамматических категорий румынского языка. Дети-румыны, проживающие в Болгарии и Словакии, были протестированы на знание материнского языка с использованием вопросительных конструкций, пассивных глаголов, категории собственности, которые включает новый разработанный тест.

Знания детей подтверждены теорией Гарсиа Коль и ее соавторов, которая развивает идею о том, что важным фактором для формирования речевых навыков ребенка является домашняя среда.

Ключевые слова: дети-румыны, румынский язык, развитие языка 


\section{История статьи:}

Поступила в редакцию: 19.06.2017

Принята к публикации: 21.08.2017

Модератор: У.М. Бахтикиреева

Конфликт интересов: отсутствует

\section{Для цитирования:}

Кючуков Х., Самко М. Развитие румынского языка у детей-дошкольников // Вестник Российского университета дружбы народов. Серия: Вопросы образования: языки и спещиальность. 2017. T. 14. № 4. C. 595-603. DOI 10.22363/2312-8011-2017-14-4-595-603

\section{Сведения об авторах:}

Кючуков Христо - доктор педагогических наук, профессор Магдебург-Стендальского университета прикладных наук, Магдебург, Германия. E-mail: hkyuchukov@gmail.com

Самко Милан - доктор философии (PhD) в области гуманитарных наук, доцент института романских исследований Университета им. Константина Философа, Нитра, Словакия. E-mail: msamko@ukf.sk 